Article

\title{
Origin and Evolution of High-Mg Carbonatitic and Low-Mg Carbonatitic to Silicic High-Density Fluids in Coated Diamonds from Udachnaya Kimberlite Pipe
}

\author{
Nikolai Gubanov ${ }^{1, *}$, Dmitry Zedgenizov ${ }^{1,2}$, Igor Sharygin ${ }^{3}$ and Alexey Ragozin ${ }^{1,2}$ (D) \\ 1 Geology and Geophysics Department, Novosibirsk State University, Novosibirsk 630090, Russia; \\ zed@igm.nsc.ru (D.Z.); ragoz@igm.nsc.ru (A.R.) \\ 2 V.S. Sobolev Institute of Geology and Mineralogy, Siberian Branch of the Russian Academy of Science, \\ Novosibirsk 630090, Russia \\ 3 Institute of the Earth's Crust, Siberian Branch of the Russian Academy of Sciences, Irkutsk 664033, Russia; \\ isharygin@igm.nsc.ru \\ * Correspondence: n.gubanov@g.nsu.ru
}

Received: 17 October 2019; Accepted: 25 November 2019; Published: 28 November 2019

\begin{abstract}
Microinclusions of high-density fluids (HDFs) were studied in coated diamonds from the Udachnaya kimberlite pipe (Siberian craton, Russia). The presence of C-centers in the coats testifies to their formation shortly before kimberlite eruption, whereas the cores have much longer mantle residence in chemically different mantle substrates, i.e., peridotite-type (P-type) and eclogite-type (E-type). The carbon isotope composition indicates an isotopically homogeneous carbon source for coats and a heterogeneous source for cores. Microinclusions in the coats belong to two groups: high-Mg carbonatitic and low- $\mathrm{Mg}$ carbonatitic to silicic. A relationship was found between high-Mg carbonatitic HDFs and peridotitic host rocks and between low-Mg carbonatitic to silicic and eclogites. The composition of high-Mg carbonatitic HDFs with a "planed" trace-element pattern can evolve to low-Mg carbonatitic to silicic during percolation through different mantle rocks. The compositional variations of microinclusions in the coats reflect this evolution.
\end{abstract}

Keywords: diamond; nitrogen; carbon isotope composition; microinclusions; HDFs; mantle

\section{Introduction}

Due to their specific physical and chemical properties, diamonds can carry primary deep mantle material which remains protected from subsequent alterations during ascent to the surface. Mineral inclusions in monocrystalline diamonds indicate that diamond formation mainly occurs in peridotitic (P-type) and eclogitic (E-type) host rocks at $P=4-7 \mathrm{GPa}$ and $T=950-1400{ }^{\circ} \mathrm{C}$ [1-3]. Mantle minerals are very rare in fibrous (including cuboid, coated, and cloudy) diamonds, but they often contain sub-micrometer inclusions (microinclusions) of fluids/melts from which the diamonds grew [4-6]. The described multiphase assemblage of such microinclusions represents a set of daughter phases of an originally homogenous liquid phase called high-density fluid (HDF), which is similar to supercritical fluids or melts enriched with volatile components [7]. The compositions of microinclusions in fibrous diamonds widely varies between three general end-members: (i) a silicic end-member rich in $\mathrm{Si}, \mathrm{Al}$, water, and $\mathrm{K}$; (ii) a saline end-member rich in $\mathrm{Cl}$, water, and $\mathrm{K}$; (iii) a carbonatitic end-member rich in carbonate, $\mathrm{Mg}, \mathrm{Ca}$, and $\mathrm{K}$ [6,8-22].

Coated diamonds consist of two contrasting growth parts: a monocrystalline core and a fibrous coat which is often enriched with numerous microinclusions. Considerable variations in the content and aggregation state of nitrogen and carbon isotopic composition between cores and coats of these crystals indicate their different thermal histories and carbon sources [18,22-26]. The formation of coats 
is considered to occur just prior to the uptake of diamonds by kimberlitic melt [22-26]. Therefore, crystallization of the coats is possibly related to protokimberlitic fluids/melts that are preserved in the coats as microinclusions.

The Udachnaya kimberlite pipe (Daldyn field, central Siberian craton; 353 to 367 Ma age [27]) is characterized by a comparatively high proportion of fibrous diamonds [11]. Previous studies focused only on the fibrous cuboid diamonds and demonstrated that the microinclusions in such diamonds from this locality predominantly reflect the carbonatitic compositions, and rare diamonds contain microinclusions enriched with silicates $[10,11,13,19]$. Here, we present the first results for coated diamonds from the Udachnaya kimberlite pipe. These results are used to constrain diamond-forming HDFs and to identify their genetic link with different host mantle substrates and kimberlitic melts.

\section{Methods}

Ten coated diamonds from the Udachnaya kimberlite pipe were selected from a current production collection of the mining company ALROSA (Mirny, Russia). The morphological features of the crystals were characterized using a Zeiss Stemi SV-6 stereoscopic microscope and a Hitachi TM-1000 electron scanning microscope (V.S. Sobolev Institute of Geology and Mineralogy, Novosibirsk, Russia). Diamonds were polished from both sides, parallel to [110] to yield thin plates $0.2-0.3 \mathrm{~mm}$ thick. The internal structure of the samples was studied in thin plates using a Zeiss Axiolab polarizing microscope and cathodoluminescence (V.S. Sobolev Institute of Geology and Mineralogy, Novosibirsk, Russia). Cathodoluminescence images were obtained using a Centaurus detector on a LEO 1430VP electron scanning microscope (V.S. Sobolev Institute of Geology and Mineralogy, Novosibirsk, Russia) at $10 \mathrm{nA}$ and $30 \mathrm{kV}$.

Fourier-transform infrared spectroscopy (FTIR) was used to characterize nitrogen and hydrogen defects in diamonds and to identify phases within the microinclusions. The spectra were recorded on a Bruker Vertex 70 FTIR spectrometer with a HYPERION 2000 microscope (V.S. Sobolev Institute of Geology and Mineralogy, Novosibirsk, Russia) in the spectral range of $600-4500 \mathrm{~cm}^{-1}$, with a resolution of $1 \mathrm{~cm}^{-1}$ and an aperture of $50 \times 50 \mu \mathrm{m}$ (signal accumulation 60 scans). The nitrogen defects in diamonds were identified through regression-based deconvolution on pure spectral types using the OPUS spectroscopy software (version 5.0, Bruker, Billerica, MA, USA). The content of each defect was calculated using the following coefficients: $\mathrm{A}(\mathrm{ppm})=16.5, \mathrm{~B}(\mathrm{ppm})=29.4$, and $\mathrm{C}(\mathrm{ppm})=37.5[28]$. The $\mathrm{H}_{2} \mathrm{O} /\left(\mathrm{H}_{2} \mathrm{O}+\mathrm{CO}_{2}\right)$ ratio in the microinclusions was estimated from the maximum intensities of the bands at $3420 \mathrm{~cm}^{-1}$ (water) and $1450 \mathrm{~cm}^{-1}\left(\mathrm{CO}_{2}\right.$ in carbonate) using the absorption coefficients proposed by Navon et al. (1988) [6]. The presence of structurally bonded hydrogen in diamonds was defined by the maximum intensity of the $3107 \mathrm{~cm}^{-1}$ peak.

Major elements of microinclusions were analyzed using an Oxford energy-dispersive X-ray spectrometer (EDS) on a Tescan MIRA scanning electron microscope (V.S. Sobolev Institute of Geology and Mineralogy, Novosibirsk, Russia). Shallow sub-surface individual microinclusions were identified in the electron backscattering mode (BSE) using a focused electron beam (15 keV, $10 \mathrm{nA})$ and analyzed with an acquisition time of 30 to $60 \mathrm{~s}$. The composition of microinclusions in each diamond was estimated from the average value of 20-40 analyses of individual microinclusions, normalized to $100 \%$ on a carbon- and oxygen-free base.

The carbon isotope compositions of the diamonds were measured on a CAMECA IMS 1270 ion mass spectrometer (SIMS) (Edinburgh Ion Microprobe Facility, The University of Edinburgh, Edinburgh, UK) following the procedure first described by Harte et al. (1999) [29]. Carbon isotopes were extracted by a primary beam of ${ }^{133} \mathrm{Cs}^{+}$ions $(6 \mathrm{nA}, 10 \mathrm{kV})$ and counted using dual Faraday cups. The data were adjusted in accordance with the synthetic diamond standard (SYNAL $\delta^{13} \mathrm{C}-23.92 \%$ o PDB), which was analyzed with the samples every 15-20 measurements. The analytical uncertainty for $\delta^{13} \mathrm{C}$ was $0.22 \%$.

The trace-element compositions of microinclusions were determined from Laser Ablation Inductively Coupled Plasma Mass Spectrometry (LA-ICP-MS) data obtained on a ThermoFisher 
Scientific XSeries II mass spectrometer combined with a New Wave Research $213 \mathrm{~nm}$ laser ablation system (Novosibirsk State University, Novosibirsk, Russia). We used the same analytical procedure described by Rege et al. (2005) [30]. Synthetic NIST 612 glass and cellulose (provided by Prof. W.L. Griffin, Macquarie University, Sydney, Australia) with a given content of rare elements were used as external multi-element doped standards (secondary standards were not used) [30]. The beam diameter was $100 \mu \mathrm{m}$, and the repetition rate was $10 \mathrm{~Hz}$. Detection limits fall between 0.001 and 1 ppm depending on the element. The data were normalized to the average Fe content derived from EDS analysis.

\section{Results}

\subsection{Morphology and Internal Structure of Diamonds}

The coated diamonds have primary morphologies that represent a combination of sculptured surfaces of octahedron, rhombic-dodecahedron, and cube (sample Ud-18, Figure 1). These forms are unevenly developed depending on the thickness of the coat: the greater the thickness, the greater the tendency for the crystal shape to be cubic [31]. Numerous trigonal pits on the octahedral surfaces may be forms of both growth and dissolution [32]. Many diamonds have common resorption features, such as rounded edges, etch-pits, and etched channels coinciding with cracks in the crystals (sample Ud-6, Figure 1). The nonuniform preservation of coats in some crystals also indicates that they were partially resorbed.
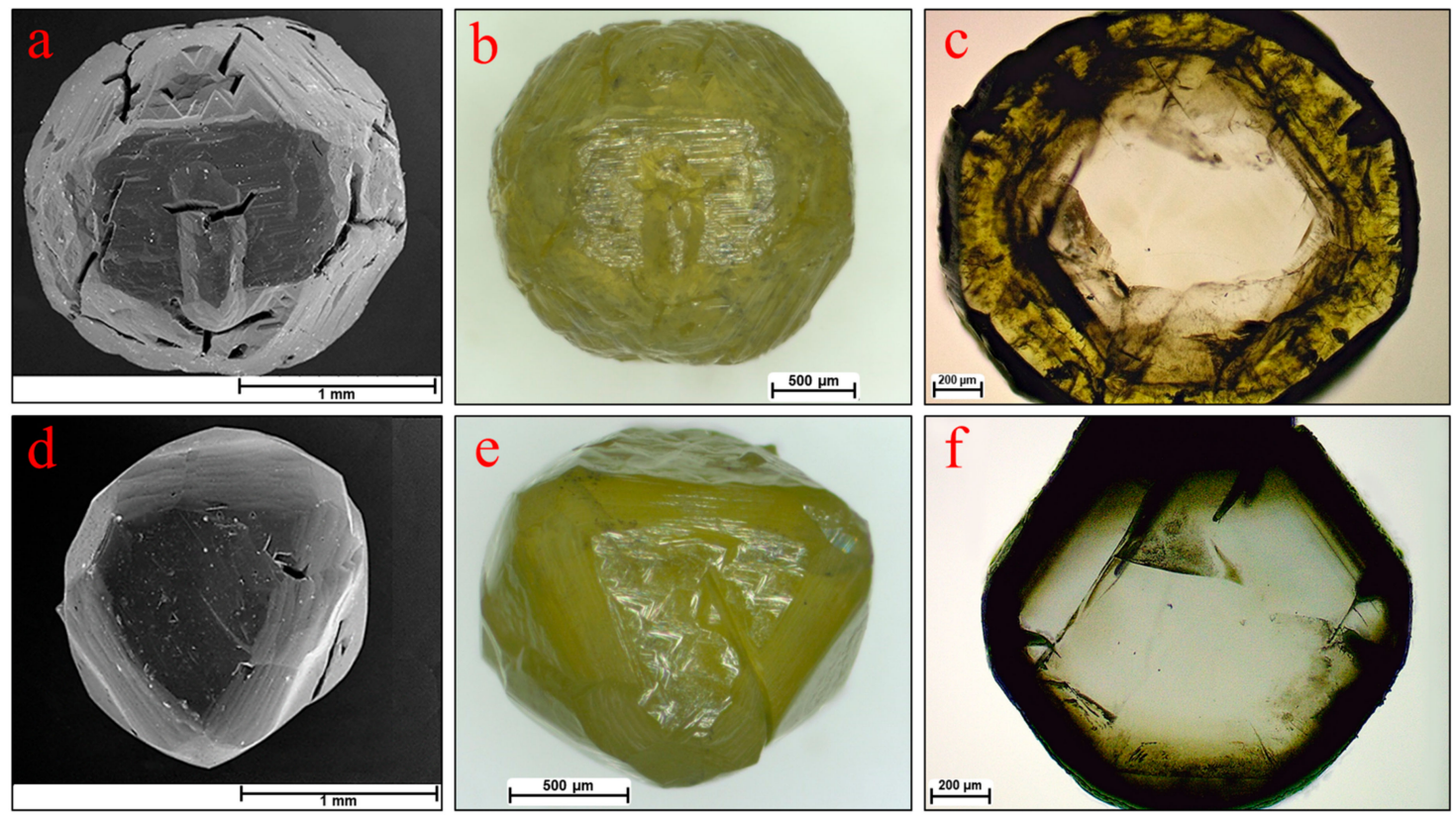

Figure 1. Morphology and internal structure of coated diamonds. (a-c) Sample Ud-18; (d-f) Sample Ud-6; (a,d) Secondary electron images; (b,e) Microphotographs (reflected light); (c,f) Polished plates (transmitted light).

All crystals show two contrasting growth domains: a colorless octahedral core and a yellowish coat (Figure 1c,f). Depending on the concentration of microinclusions, the coats may be transparent, semi-transparent, or almost opaque. The cathodoluminescence images in many cases display linear octahedral growth zonation of the cores, whereas the coats have concentric curved zonation (Figure 2). The internal structure of the coats consists of fibers developed in the [111] direction. The marked differences of two growth domains of the coated diamonds are considered to indicate a change of growth mechanism from layer-by-layer in cores to adhesive in coats. This change is traditionally attributed to an increase in the growth rate caused by carbon oversaturation in the diamond-forming media [33]. 

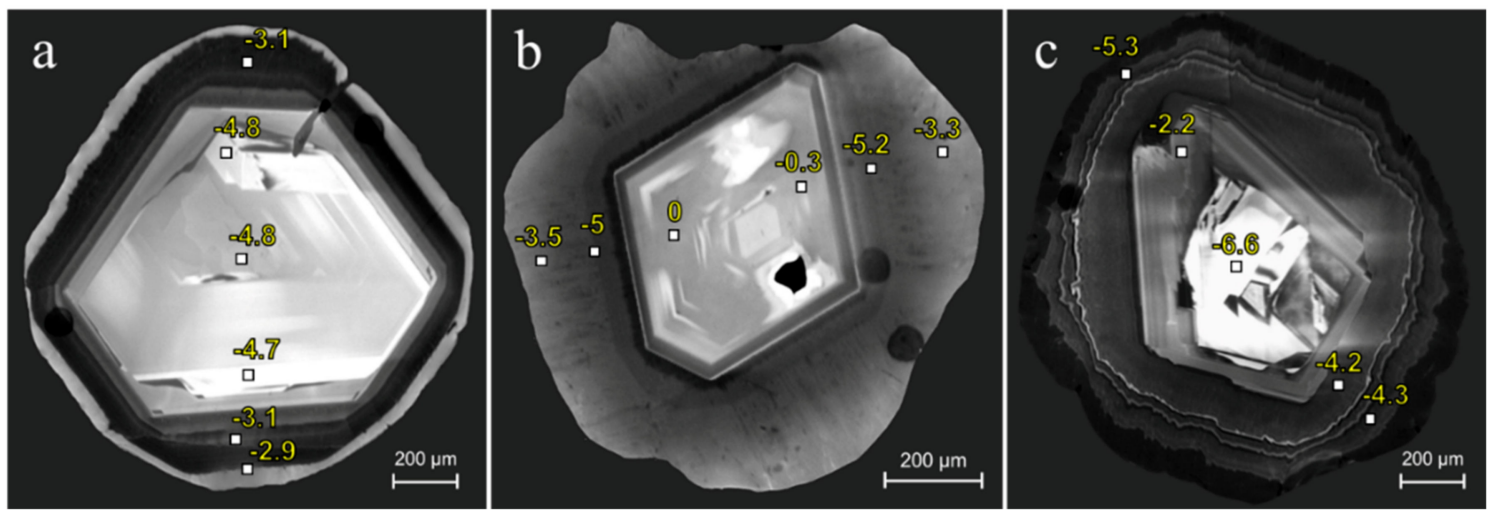

Figure 2. Cathodoluminescence images of internal structure of coated diamonds. (a) Sample Ud-6; (b) Sample Ud-10; (c) Sample Ud-13. Numbers reflect the carbon isotope composition $\left(\delta^{13} \mathrm{C}, \%\right.$ o .

\subsection{Impurity Defects}

The main structural impurity in natural diamonds is nitrogen [34]. The nitrogen in diamonds may be incorporated in several main forms, which have specific infrared absorption: A-defect (two N atoms in neighboring positions [35]), B-defect (four N atoms around a vacancy [36]), and C-defect (a single nitrogen atom [37]).

The nitrogen defects in the cores and coats of the studied samples differ significantly (Table 1). The total nitrogen content varies from 660 to 1419 ppm in the coats and from 62 to 1241 ppm in the cores. Nitrogen content in individual crystals is higher in the coats (Figure 3). Aggregated B-defects are recorded exclusively in the cores. The content of B-defects gradually decreases from the center to the rim of the cores. The aggregation state $(\% \mathrm{~B}=\mathrm{B} \times 100 \% /(\mathrm{A}+\mathrm{B}))$ in the center of the core of some crystals reaches $60-74 \%$ (samples Ud-4, Ud-13, Ud-17). The FTIR spectra of cores also show the presence of B'-defects (platelets-extended planar defects in the [100] planes represented by carbon interstitials [38]). The absorption of B'-defects is linearly correlated with the absorption of B-defects [39]. The coats contain nitrogen in the form of A- and C-defects. The presence of C-defects causes a yellow coloration of the coats. The concentration of C-defects in the coats of the samples Ud-10, Ud-17, and Ud-22 is very low and could not be estimated. In all other samples, the concentration of C-defects increases towards the outer parts of the coats (Figure 3).

The sharp peak at $3107 \mathrm{~cm}^{-1}$ in the FTIR spectra is attributed to structurally bonded hydrogen in the diamond lattice [40]. The maximum intensity of this peak may be higher either in the core (up to $27.0-29.3 \mathrm{~cm}^{-1}$ in samples Ud-13, Ud-21, and Ud-22) or in the coat. The coats show a positive correlation between the hydrogen absorption and the total nitrogen content whereas the cores do not. This correlation suggests that the conditions during the formation of the coats favor the simultaneous incorporation of nitrogen and hydrogen.

\subsection{Mineral Inclusions}

The cores of some diamonds contain mineral macroinclusions. Coesite (proved by Raman spectroscopy) and omphacite $\left(\mathrm{Na}_{0.35} \mathrm{Ca}_{0.38}\right)\left(\mathrm{Mg}_{0.51} \mathrm{Fe}_{0.46} \mathrm{Al}_{0.34}\right)\left[\mathrm{Si}_{1.99} \mathrm{O}_{6}\right]$ were detected in sample Ud-4. Omphacite $\left(\mathrm{Na}_{0.38} \mathrm{Ca}_{0.51}\right)\left(\mathrm{Mg}_{0.51} \mathrm{Fe}_{0.19} \mathrm{Al}_{0.4}\right)\left[\mathrm{Si}_{2} \mathrm{O}_{6}\right]$ was also found in sample Ud-13. The omphacites have a $\mathrm{TiO}_{2}$ impurity: $0.63 \mathrm{wt} \%$ in $\mathrm{Ud}-4$ and $0.74 \mathrm{wt} \%$ in Ud-13. The inclusions of omphacite and coesite are typical for E-type parageneses [1-3]. The core of sample Ud-10 contains inclusions of olivine $\left(\mathrm{Mg}_{1.83} \mathrm{Fe}_{0.17}\right)\left[\mathrm{SiO}_{4}\right]$ and $\mathrm{Cr}$-diopside $\left(\mathrm{Na}_{0.35} \mathrm{Ca}_{0.5}\right)\left(\mathrm{Mg}_{0.66} \mathrm{Fe}_{0.15} \mathrm{Al}_{0.23} \mathrm{Cr}_{0.14}\right)\left[\mathrm{Si}_{1.98} \mathrm{O}_{6}\right]$. Cr-diopside contains a high kosmochlor component $(\mathrm{NaCr})$ which is typical for lherzolitic paragenesis [41]. Olivine has high $\mathrm{Mg \#} \mathrm{(0.91)} \mathrm{and} \mathrm{contains} \mathrm{a} \mathrm{significant} \mathrm{amount} \mathrm{of} \mathrm{NiO}(0.46 \mathrm{wt} \%)$ which falls close to previously described olivine inclusions in diamonds from the same kimberlite pipe [42]. In the core of sample $\mathrm{Ud}-17$, we found the inclusion of orthopyroxene $\left(\mathrm{Mg}_{1.83} \mathrm{Fe}_{0.17}\right)\left[\mathrm{Si}_{2} \mathrm{O}_{6}\right]$. The association of olivine, orthopyroxene, and $\mathrm{Cr}$-diopside indicates a P-type paragenesis. Thus, the mineral inclusions in the 
cores of the studied coated diamonds indicate their formation in chemically different mantle substrates, i.e., eclogitic or peridotitic.

Table 1. Defect, impurity, and carbon isotope composition of coated diamonds from Udachnaya

\begin{tabular}{|c|c|c|c|c|c|c|c|}
\hline \multicolumn{2}{|c|}{ Sample } & \multirow{2}{*}{$\begin{array}{l}\text { N, ppm } \\
540-695\end{array}$} & \multirow{2}{*}{$\begin{array}{c}\text { \% B } \\
51-62\end{array}$} & \multirow{2}{*}{$\frac{\mathbf{B}^{\prime}, \mathbf{c m}^{-\mathbf{1}}}{9-14}$} & \multirow{2}{*}{$\frac{\mathrm{C}, \mathrm{ppm}}{-}$} & \multirow{2}{*}{$\frac{\mathbf{H}_{\mathbf{3 1 0 7}}, \mathbf{c m}^{-\mathbf{1}}}{2.5-3.5}$} & \multirow{2}{*}{$\begin{array}{c}\delta^{13} C_{,} \% \text { o } \\
-1.4 \cdots-1.3\end{array}$} \\
\hline IId 4 & Core & & & & & & \\
\hline Ud-4 & Coat & 725-1094 & 0 & - & 100-188 & $1-2$ & $-4.4 \cdots-2.9$ \\
\hline \multirow{2}{*}{ Ud-6 } & Core & 780-1013 & $33-38$ & $10-13.7$ & - & $1.2-1.6$ & $-4.8 \cdots-4.0$ \\
\hline & Coat & $1001-1112$ & 0 & - & $75-308$ & $0.14-5$ & $-3.1 \cdots-2.9$ \\
\hline \multirow{2}{*}{ Ud-10 } & Core & 879-995 & $27-31$ & $10.2-12.7$ & - & $0.1-0.6$ & $-0.3 \cdots 0.0$ \\
\hline & Coat & 660-1155 & 0 & - & 0 & $1.5-4.1$ & $-5.2 \cdots-3.3$ \\
\hline \multirow{2}{*}{ Ud-12 } & Core & 718-958 & $17-37$ & $7.4-16.8$ & - & $0-2$ & - \\
\hline & Coat & $942-986$ & 0 & - & 56-131 & $0.7-1$ & - \\
\hline \multirow{2}{*}{ Ud-13 } & Core & 761-1069 & $20-60$ & $9.2-13.3$ & - & 4-27 & $-6.6 \cdots-2.2$ \\
\hline & Coat & 1247-1419 & 0 & - & 49-113 & $2.9-6.6$ & $-5.3 \cdots-4.2$ \\
\hline \multirow{2}{*}{ Ud-14 } & Core & $488-645$ & $14-26$ & $2-5.7$ & - & $0.1-0.5$ & - \\
\hline & Coat & $709-840$ & 0 & - & $45-86$ & $0.3-0.8$ & - \\
\hline \multirow{2}{*}{ Ud-17 } & Core & $62-506$ & $17-74$ & $0.4-2$ & - & $1-7.4$ & $-6.7 \cdots-5.3$ \\
\hline & Coat & 964-1011 & 0 & - & 0 & $2.2-2.8$ & -3.8 \\
\hline \multirow{2}{*}{ Ud-18 } & Core & 840-1105 & $21-36$ & $3.6-13.4$ & - & $0.4-2.9$ & $-4.0 \cdots-2.6$ \\
\hline & Coat & $1069-1175$ & 0 & - & $60-71$ & $1.8-2.6$ & $-5.6 \cdots-3.7$ \\
\hline \multirow{2}{*}{ Ud-21 } & Core & 825-909 & $15-20$ & $1.7-5.1$ & - & $0.1-25$ & $-5.2 \cdots-4.6$ \\
\hline & Coat & 1180-1315 & 0 & - & $38-71$ & $1.8-2.6$ & $-5.9 \cdots-5.8$ \\
\hline \multirow{2}{*}{ Ud-22 } & Core & 776-1241 & $18-24$ & $1.6-6.7$ & - & $6-29.3$ & $-6.3 \cdots-4.4$ \\
\hline & Coat & $1035-1216$ & 0 & - & 0 & $2.1-2.7$ & $-5.7 \cdots-4.9$ \\
\hline
\end{tabular}
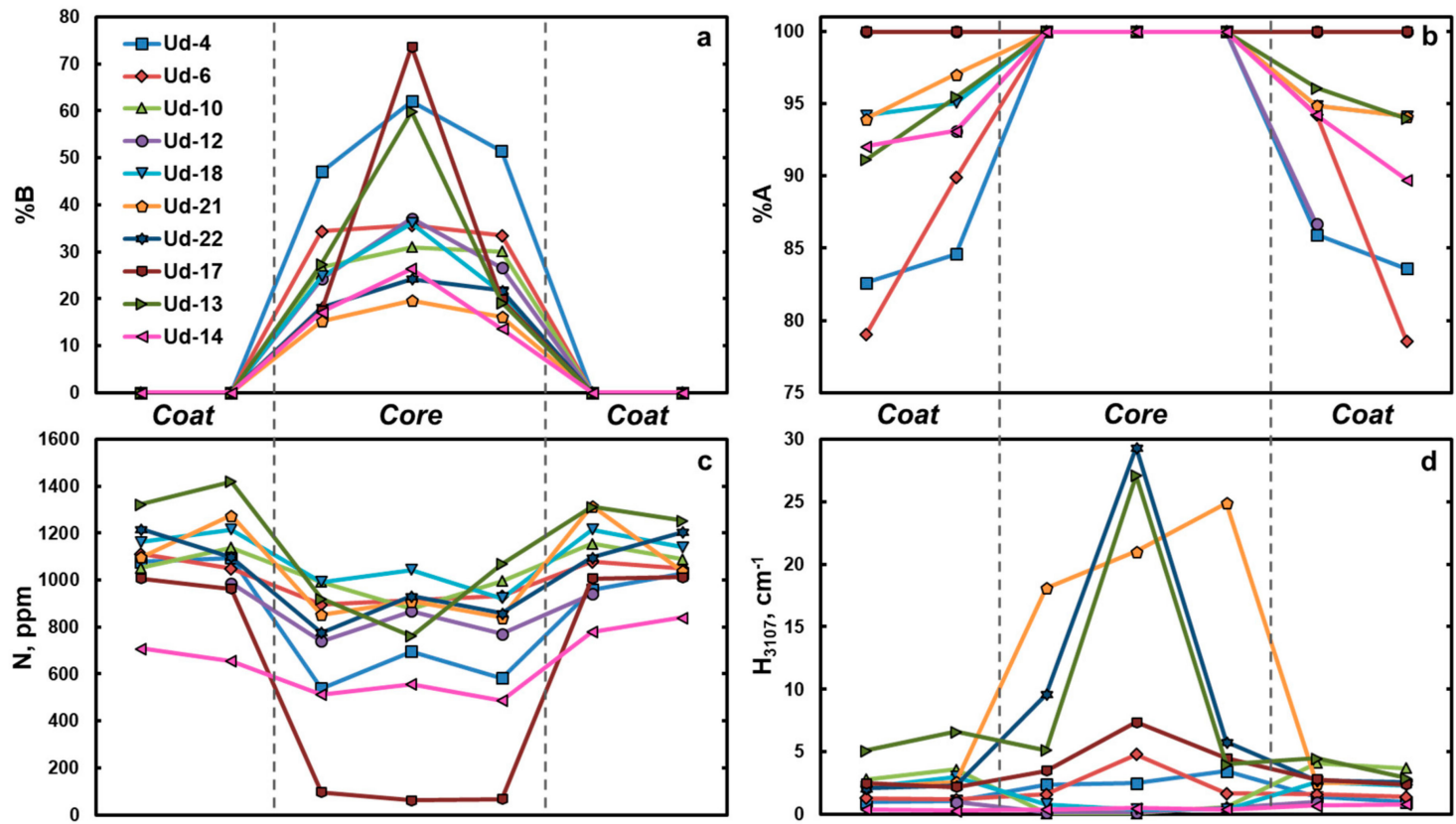

Figure 3. Profiles of nitrogen aggregation $\% \mathrm{~B}=\mathrm{B} \times 100 \% /(\mathrm{A}+\mathrm{B})(\mathbf{a})$ and $\% \mathrm{~A}=\mathrm{A} \times 100 \% /(\mathrm{A}$ $+\mathrm{C})(\mathbf{b})$, total nitrogen content $\mathrm{N}$ (c) and hydrogen absorption $\mathrm{H}_{3107}(\mathbf{d})$ in coated diamonds from Udachnaya pipe.

\subsection{Carbon Isotope Composition}

The carbon isotope composition $\left(\delta^{13} \mathrm{C}\right)$ varies from $-5.9 \%$ o to $-2.9 \%$ o in the coats and from $-6.7 \%$ to 0 in the cores (see Table 1 and Figure 4). The carbon isotope composition may be heavier (i.e., samples Ud-4 and Ud-10), or lighter (i.e., samples Ud-6 and Ud-17) in the core or almost equal in the core and coat (sample Ud-18). However, the differences in most cases do not exceed 2-3\%o (except in 
sample Ud-10 where $\delta^{13} \mathrm{C}$ shifts from 0 to $-5 \%$ from the core to the rim-Figure 4$)$. The cores of some individual diamonds show some variations which correspond to different growth zones $(-2.2 \%$ o at the center and $-6.6 \%$ at the outer zone of the core in the sample Ud-13-Figure 2). No relation between mineral inclusions found in the cores of several diamonds and their carbon isotope composition is observed. This may be due to the limited range of $\delta^{13} \mathrm{C}$ values detected in the cores of the studied diamonds, which corresponds to the typical range for the majority of peridotitic and eclogitic diamonds from worldwide localities [43].

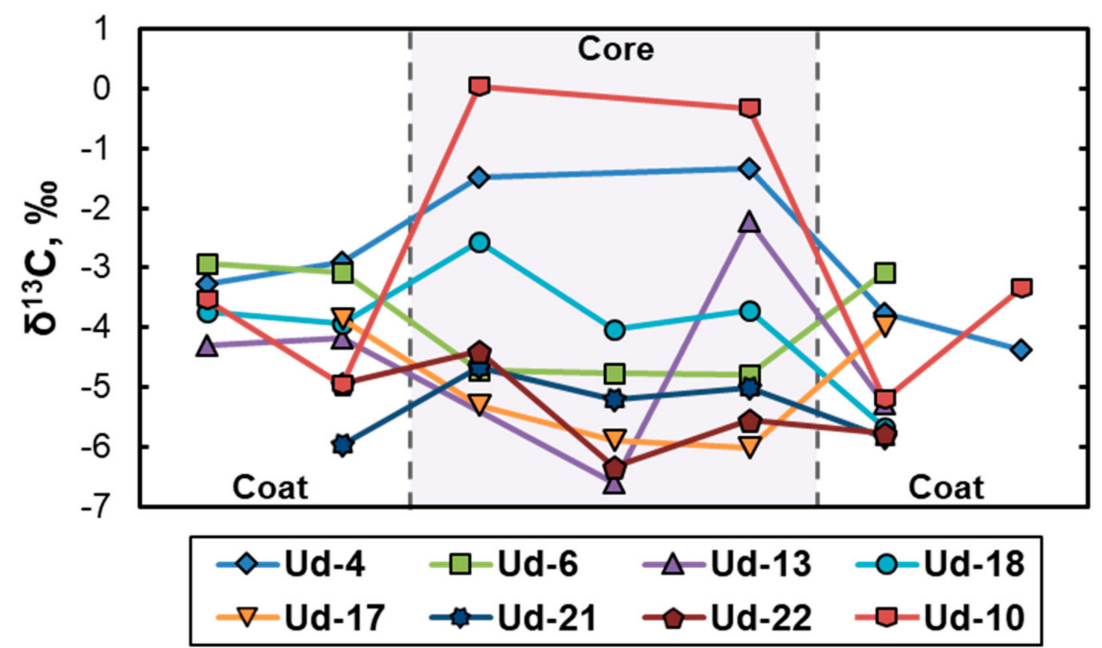

Figure 4. Variations in the carbon isotope composition $\left(\delta^{13} \mathrm{C}\right)$ within individual coated diamonds from Udachnaya pipe.

\subsection{Microinclusions}

The coats of all studied diamonds contain numerous microinclusions. FTIR spectra of coats show the presence of water $\left(3420 \mathrm{~cm}^{-1}\right.$ and $\left.1650 \mathrm{~cm}^{-1}\right)$, carbonates $\left(1450 \mathrm{~cm}^{-1}, 880 \mathrm{~cm}^{-1}\right.$ and/or $840 \mathrm{~cm}^{-1}$ ) and silicates (1000-1200 $\mathrm{cm}^{-1}$ ) (Figure A1). The intensity of these absorptions depends on the density of microinclusions and the relative amounts of the absorbing phases. The water/carbonate ratio $\left(\mathrm{H}_{2} \mathrm{O} /\left(\mathrm{H}_{2} \mathrm{O}+\mathrm{CO}_{2}\right)\right)$ in microinclusions in the coats of the studied diamonds varies widely from 0.09 to 0.65 . Water-rich microinclusions are generally characterized by high intensity of silicate peaks and often show the presence of a free $\mathrm{SiO}_{2}$-phase (quartz- $810 \mathrm{~cm}^{-1}$ and $785 \mathrm{~cm}^{-1}$ ). Carbonate-rich microinclusions have a relatively low abundance of silicates which is generally positively correlated with water content.

Major element compositions of microinclusions in the coats vary considerably (Table 2). The combined concentration of $\mathrm{SiO}_{2}+\mathrm{Al}_{2} \mathrm{O}_{3}$ varies from 6.3 to $73.4 \mathrm{wt} \%$. The higher values are observed in diamonds rich in silicates and water and the $\mathrm{SiO}_{2}+\mathrm{Al}_{2} \mathrm{O}_{3}$ content positively correlates with the water/carbonate ratio. The combined concentration of oxides of divalent cations $(\mathrm{FeO}+\mathrm{MgO}$ $+\mathrm{CaO}$ ) varies from 14.2 to $66.2 \mathrm{wt} \%$ with higher concentrations corresponding to carbonate-rich samples indicating their accommodation in carbonate phases. Carbonate-rich microinclusions have a low amount of $\mathrm{FeO}$ whereas most water- and silicate-rich microinclusions are enriched in FeO (up to $17.1 \mathrm{wt} \%)$. The combined concentrations of alkalis $\left(\mathrm{Na}_{2} \mathrm{O}+\mathrm{K}_{2} \mathrm{O}\right)$ in the microinclusions varies from 10.4 to $33.8 \mathrm{wt} \%$. The highest content of alkalis is observed in sample Ud-10 where microinclusions are also enriched in $\mathrm{Cl}$ (up to $12 \mathrm{wt} \%$ ). Similar features are fixed in low-Mg carbonatitic microinclusions in cuboid diamonds from the Udachnaya pipe, some of which have elevated amounts of $\mathrm{Cl}$ (up to $18.6 \mathrm{wt} \%$ ) [11,19]. The content of $\mathrm{MgO}$ in all studied samples has a clear negative correlation with $\mathrm{SiO}_{2}$ and a positive correlation with the $\mathrm{H}_{2} \mathrm{O} /\left(\mathrm{H}_{2} \mathrm{O}+\mathrm{CO}_{2}\right)$ ratio (Figure 5). 
Table 2. Composition of microinclusions from coated diamonds, wt \%

\begin{tabular}{ccccccccccc}
\hline Sample & Ud-4 & Ud-6 & Ud-10 & Ud-12 & Ud-13 & Ud-14 & Ud-17 & Ud-18 & Ud-21 & Ud-22 \\
\hline $\mathbf{n} \mathbf{1}$ & $\mathbf{2 2}$ & $\mathbf{2 0}$ & $\mathbf{1 5}$ & $\mathbf{1 7}$ & $\mathbf{1 6}$ & $\mathbf{3 1}$ & $\mathbf{2 4}$ & $\mathbf{2 5}$ & $\mathbf{1 5}$ & $\mathbf{1 8}$ \\
\hline $\mathrm{SiO}_{2}$ & 50.1 & 60.0 & 6.0 & 31.5 & 58.4 & 9.39 & 9.97 & 45.1 & 49.9 & 63.6 \\
$\mathrm{TiO}_{2}$ & 3.63 & 3.94 & - & 2.34 & 2.15 & 1.36 & - & 3.83 & 4.74 & 2.81 \\
$\mathrm{Al}_{2} \mathrm{O}_{3}$ & 5.28 & 6.75 & 0.30 & 5.52 & 8.70 & 2.49 & 0.65 & 7.52 & 5.27 & 9.80 \\
$\mathrm{FeO}$ & 14.2 & 9.72 & 9.57 & 11.1 & 8.92 & 13.6 & 7.47 & 10.4 & 17.1 & 7.39 \\
$\mathrm{MgO}$ & 7.37 & 3.10 & 20.9 & 10.3 & 3.98 & 18.9 & 30.7 & 2.11 & 8.12 & 3.83 \\
$\mathrm{CaO}$ & 4.24 & 1.40 & 11.8 & 9.11 & 1.49 & 33.7 & 18.7 & 5.71 & 1.97 & 0.79 \\
$\mathrm{Na}_{2} \mathrm{O}$ & 2.19 & 1.25 & 13.3 & 3.89 & 0.35 & 6.23 & 9.99 & 1.03 & 0.62 & 0.51 \\
$\mathrm{~K}_{2} \mathrm{O}$ & 11.4 & 11.9 & 20.6 & 18.3 & 12.1 & 9.90 & 16.0 & 14.3 & 9.78 & 10.1 \\
$\mathrm{BaO}$ & - & 0.17 & 4.41 & 1.11 & 1.73 & 0.10 & 0.44 & 2.48 & 0.21 & 0.23 \\
$\mathrm{P}_{2} \mathrm{O} 5$ & 0.97 & 0.98 & 1.27 & 3.74 & 1.36 & 2.64 & 3.46 & 5.85 & 1.26 & 0.61 \\
$\mathrm{Cl}$ & 0.74 & 0.72 & 12.0 & 3.18 & 0.85 & 1.59 & 2.16 & 1.60 & 1.06 & 0.35 \\
$\mathrm{w} / \mathrm{c}$ & 0.32 & 0.55 & 0.11 & 0.31 & 0.50 & 0.24 & 0.09 & 0.24 & 0.65 & 0.65 \\
\hline
\end{tabular}

${ }^{1}$ Number of averaged analyses. ${ }^{2}$ water/carbonate ratio: $\mathrm{H}_{2} \mathrm{O} /\left(\mathrm{H}_{2} \mathrm{O}+\mathrm{CO}_{2}\right)$.
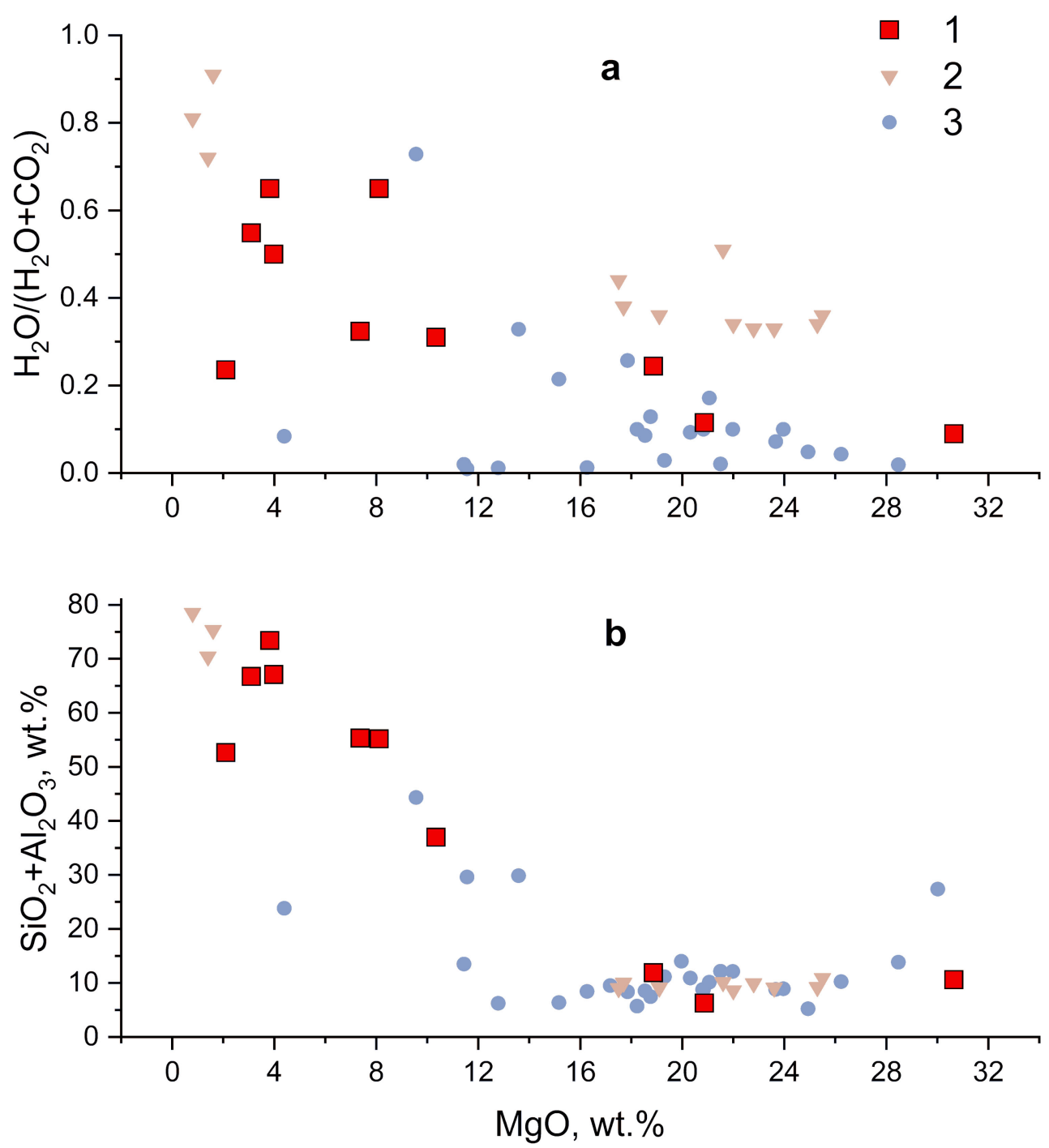

Figure 5. $\mathrm{H}_{2} \mathrm{O} /\left(\mathrm{H}_{2} \mathrm{O}+\mathrm{CO}_{2}\right)\left(\right.$ a) and $\mathrm{SiO}_{2}+\mathrm{Al}_{2} \mathrm{O}_{3}$ (b) versus $\mathrm{MgO}$ content of microinclusions from coated diamonds from Udachnaya pipe (1), compared with microinclusions from the same pipe from previous studies Klein-BenDavid et al. (2009) (2), and Zedgenizov et al. (2007) (3) [11,19]. 
Based on their major element compositions, the microinclusions in the coats of the studied diamonds can be divided into two groups: (i) high-Mg carbonatitic, and (ii) low-Mg carbonatitic to silicic (Figure 6). These groups differ in the content of $\mathrm{SiO}_{2}+\mathrm{Al}_{2} \mathrm{O}_{3}$, which is $<13 \mathrm{wt} \%$ in carbonatitic and $>40 \mathrm{wt} \%$ in silicic microinclusions. The carbonatitic microinclusions are most common in fibrous cuboid diamonds from Udachnaya $[10,11,13]$. Rare cuboid diamonds in this locality are reported to contain microinclusions enriched with silicates [19]. In the coats of the studied diamonds, the silicic compositions of microinclusions are predominant whereas carbonatitic compositions are rare. Moreover, high-Mg carbonatitic microinclusions are observed in diamonds with P-type mineral inclusions in the cores (samples Ud-10 and Ud-17) and low-Mg carbonatitic to silicic microinclusions are observed in diamonds with E-type mineral inclusions in the cores (samples Ud-4 and Ud-13). P-type mineral inclusions (Cr-diopside, olivine, and chromite) were also found in fibrous diamond from Diavik with microinclusions of saline to high-Mg carbonatitic HDFs [21].

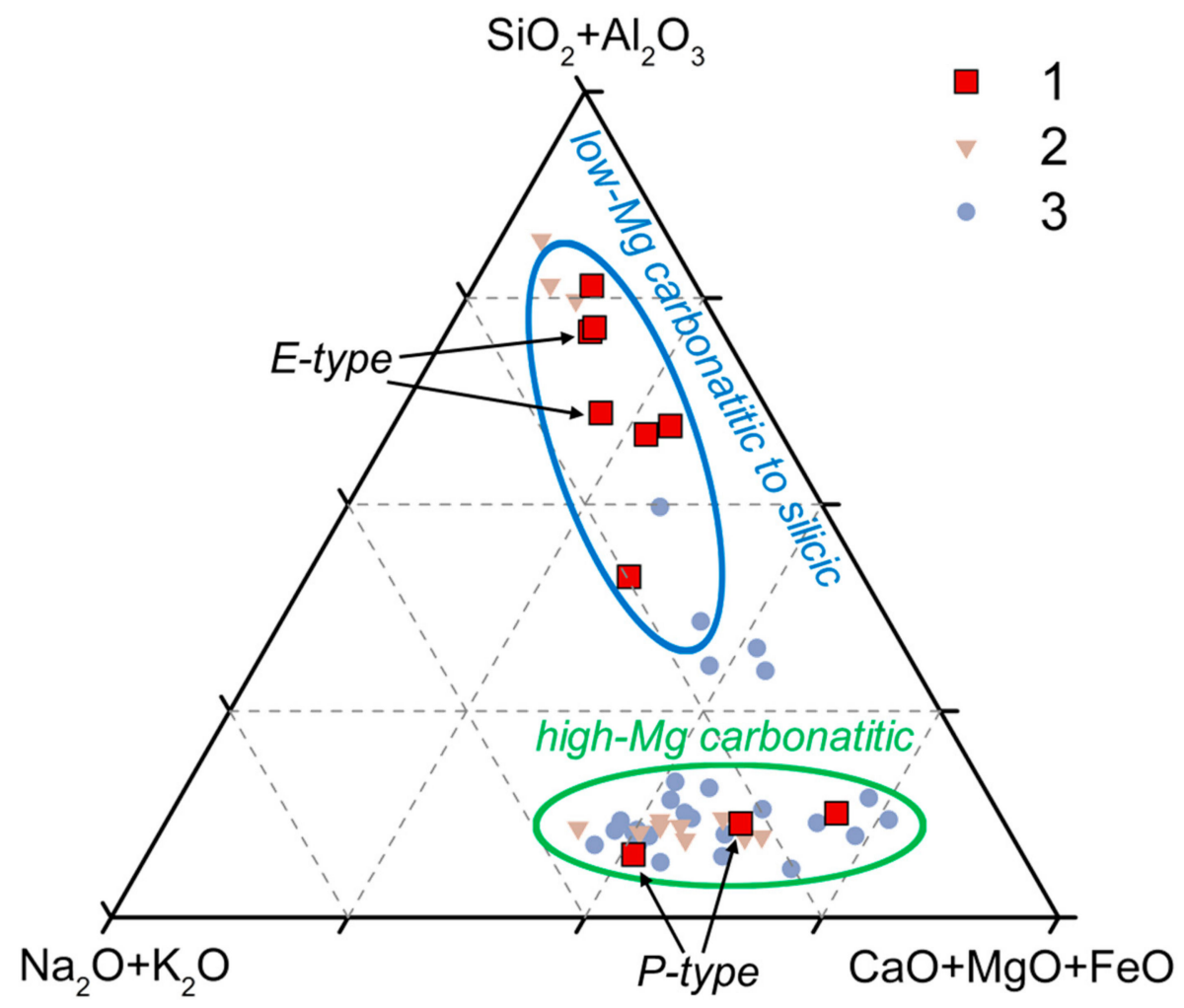

Figure 6. Compositional features of microinclusions (wt \%) from coated diamonds from Udachnaya pipe (1), compared to available data on microinclusions in fibrous cuboid diamonds from the same pipe from previous studies Klein-BenDavid et al. (2009) (2), and Zedgenizov et al. (2007) (3) [11,19].

The PM [44] normalized trace-element patterns of microinclusions in the coats are presented in Figure 7 (Table A1). All samples show enrichment in LREE and strong depletion in Ti. Microinclusions in most samples are depleted in Ta and $\mathrm{Nb}$. The only exception is sample Ud-17 with higher Ta and $\mathrm{Nb}$ concentrations, similar to previously reported trace-element patterns of microinclusions in Udachnaya cuboid diamonds, which showed a considerable depletion in Ti and $\mathrm{Y}$, and mild depletion in $\mathrm{K}, \mathrm{Sr}$, $\mathrm{Hf}$, and $\mathrm{Zr}$ [11]. Some of the studied coats also have lower concentrations of Sr and Y. In some cases, microinclusions in the coats demonstrate specific anomalies (i.e., negative Ta and positive La anomalies in sample Ud-12, and positive $\mathrm{Hf}$ and Eu anomalies in sample Ud-21). 
Compared to the host kimberlites [45] the trace-element patterns of microinclusions in coats are characterized by the enrichment of $\mathrm{K}$ and depletion of $\mathrm{Ta}, \mathrm{Nb}$, and $\mathrm{Ti}$ (Figure 7). All samples show the gentle negative slope of REE. The distribution from La to Sm has a narrow range of values, whereas wide variations are marked for heavier REE. Microinclusions in some coats are enriched with $\mathrm{Zr}$ and Hf.

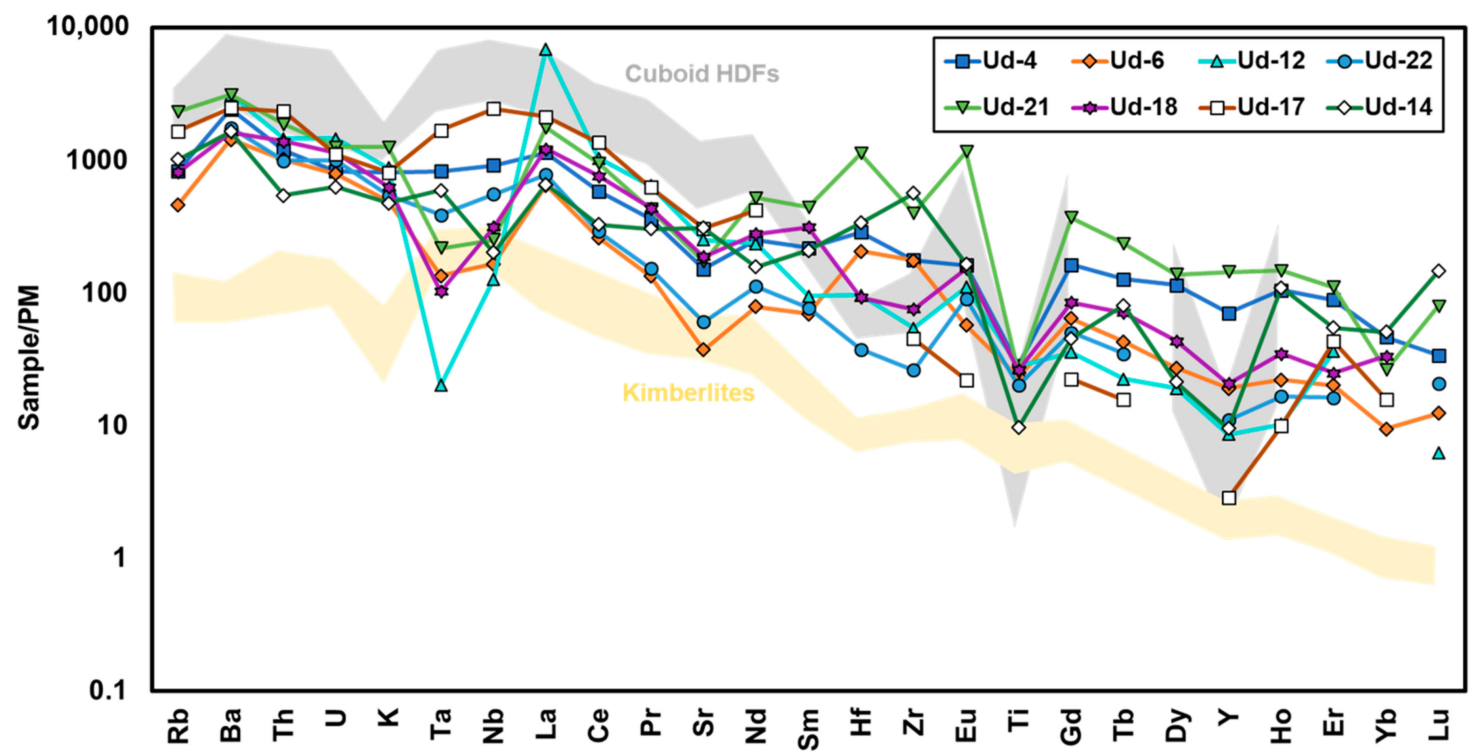

Figure 7. Primitive-mantle-normalized trace-element patterns of microinclusions from the coats of the studied diamonds. White spots represent high-Mg carbonatitic HDFs and colored spots represent low-Mg carbonatitic to silicic HDFs. The greyish area covers the range of incompatible elements in cuboid diamonds from Udachnaya pipe [11] and the yellowish area corresponds to kimberlites from the same pipe [45].

\section{Discussion}

\subsection{Thermal History of Coated Diamonds}

The content and aggregation state of nitrogen can potentially provide information on the residence time and temperature of diamonds in the mantle. It was experimentally shown that, at high mantle temperatures, C-defects are unstable and rapidly transform into A-defects [46]. This is probably the reason for the rarity of natural type $\mathrm{Ib}$ diamonds [24]. During continuous heat treatment, nitrogen aggregation proceeds to form B-defects and platelets ( $B^{\prime}$ defect). The vast majority of natural diamonds belong to type Ia, i.e., they contain both A- and B-defects.

The presence of $\mathrm{C}$ centers in the coats of most of the studied diamonds suggests short residence time in the mantle and indicates that formation occurred shortly before transport to the surface by kimberlite magmas. The high nitrogen aggregation state (14-74 \%B) in the cores suggests a much longer residence time with a significant time gap between formation and the growth of the coats. The temperature range for the formation of the kimberlitic melt at 6-7 GPa falls between $1400{ }^{\circ} \mathrm{C}$ and $1600{ }^{\circ} \mathrm{C}$ [47]. Homogenization of fluid/melt microinclusions in cuboid diamonds at 6 GPa occurs at temperatures of $1400-1500{ }^{\circ} \mathrm{C}$ [48]. These temperatures are used to estimate the annealing time and the duration of the growth of the coats in the studied diamonds. The annealing time was estimated from the C-to A-defects ratio using kinetic parameters proposed by Taylor et al. (1996). In the inner parts of the coats, the annealing time is $100-200$ days at $1500^{\circ} \mathrm{C}$ and $3-5$ years at $1400{ }^{\circ} \mathrm{C}$ [49]. The difference in the annealing time between the inner and outer parts of the coats suggests that their growth might proceed within $50-100$ days at $1500{ }^{\circ} \mathrm{C}$ and within $1-3$ years at $1400{ }^{\circ} \mathrm{C}$. 


\subsection{Carbon Sources}

The carbon isotope composition of diamonds is generally used as the main indicator of the source of diamond-forming fluids/melts. Fluctuations of $\delta^{13} \mathrm{C}$ values in natural diamonds have been attributed to several reasons: (i) isotopic fractionation during fluid/melt transfer $[25,50]$ and during diamond growth [51,52]; (ii) primary heterogeneous distribution of carbon in the mantle [53]; and (iii) addition of isotopically heterogeneous carbon with subducted slabs [54,55]. Diamonds of peridotitic paragenesis have a narrow carbon isotope composition range, with the maximum in the distribution occurring near $-5 \%$ o $\delta^{13} \mathrm{C}$; this value corresponds to the assumed average of the upper mantle [43]. Eclogitic diamonds generally have a wider range of $\delta^{13} \mathrm{C}$ from $+3 \%$ o to $-34 \%$, however, they commonly lie near the average mantle value.

The $\delta^{13} \mathrm{C}$ in the cores of the studied coated diamonds from Udachnaya varies from $-6.7 \%$ o to 0 , whereas the coats have a narrower range from $-5.9 \%$ to $-2.9 \%$. Both ranges are closely similar to values typical for most peridotitic and eclogitic diamonds and are not significantly shifted from the average mantle value. No significant differences in the carbon isotope composition were found between the cores with mineral inclusions of eclogitic and peridotitic parageneses. Each coat has very low variations of $\delta^{13} \mathrm{C}$ suggesting they were formed from isotopically homogeneous fluids/melts. The cores in some diamonds show significant variations, which is probably explained by the fractionation of carbon species during diamond growth or the input of new fluids/melts having different carbon sources [25,49-51].

\subsection{Origin and Evolution of HDFs}

The compositions of HDF microinclusions in fibrous diamonds from worldwide deposits are known to vary between three main end-members: silicic, saline, and carbonatitic [6,8-22]. These data were used to constrain many possible scenarios of the origin and evolution of such HDFs. Schrauder and Navon (1994) first proposed that the evolution of HDFs from carbonatitic to silicic compositions was due to the fractionation of carbonates [8]. Perchuk et al. (2002) suggested that the formation of saline fluids/melts occurs with active participation of processes associated with immiscibility [56]. It was then suggested that primary carbonatitic melts evolve through fractionation to immiscible silicic and saline HDFs [18,57]. However, experimental results showed that upon cooling in a dry silicate-carbonate-chloride system, the compositions of immiscible saline and silicic liquids evolve toward a homogeneous carbonatitic melt [58]. Weiss et al. (2009) suggested that high-Mg carbonatitic HDFs are formed through interaction of hydrous saline fluids with carbonated peridotites, whereas the low-Mg carbonatitic to silicic HDFs result from percolation of hydrous fluids through eclogites [20].

The trace-element patterns of microinclusions in most of the studied diamonds are enriched in $\mathrm{Ba}$, $\mathrm{Th}, \mathrm{U}$, and LREE and depleted in $\mathrm{Rb}, \mathrm{Ta}, \mathrm{Nb}$, and Ti. Such distributions are similar to the previously determined "ribbed" pattern of HDFs [59]. Only sample Ud-17 does not show depletion in Rb, Ta, and $\mathrm{Nb}$ and thus is more similar to a "planed" pattern [59]. The same trace element patterns are typical for high-Mg carbonatitic HDFs in cuboid diamonds from Udachnaya [11]. "Ribbed" and "planed" types can be distinguished by their $\mathrm{Th} / \mathrm{Nb}$ and $\mathrm{La} / \mathrm{Nb}$ ratios (Figure 8). Weiss et al. (2013) suggested that the "ribbed" pattern occurs as a result of the percolation of HDFs with an original "planed" pattern through metasomatized mantle rocks with phlogopite, ilmenite, and rutile [59]. The HDFs with a "planed" pattern do not require a pre-enriched source and may originate from the asthenosphere. Following this suggestion, high-Mg carbonatitic HDFs with a "planed" pattern can evolve to low-Mg carbonatitic to silicic compositions during their percolation through different mantle rocks. Thus, HDFs can be trapped during coat growth very soon after entry and hold their "planed" pattern, or they may interact with different mantle rocks to form a "ribbed" distribution of trace-elements in the microinclusions. 


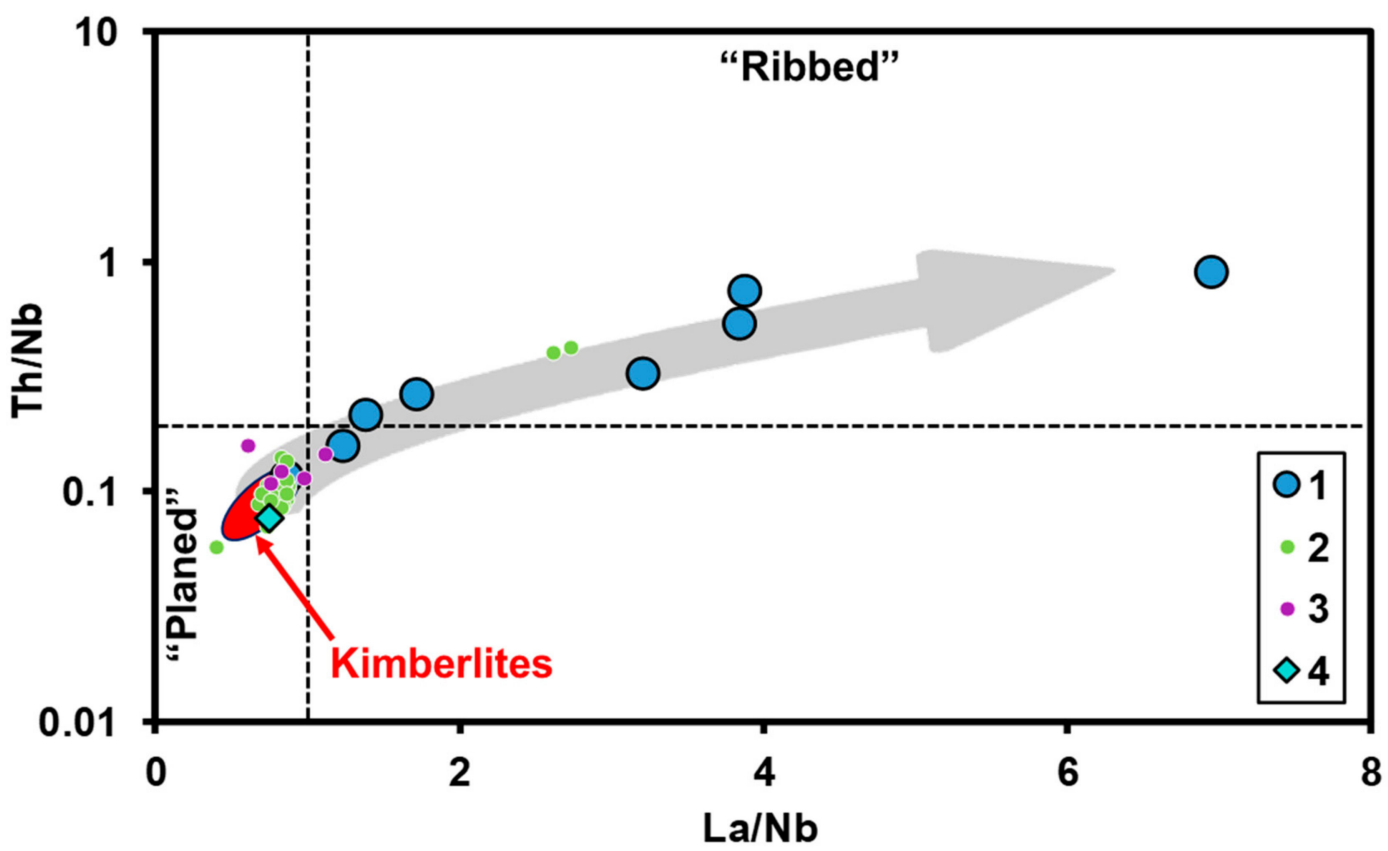

Figure 8. $\mathrm{Th} / \mathrm{Nb}$ versus $\mathrm{La} / \mathrm{Nb}$ ratios of microinclusions in studied coated diamonds (1); compared with microinclusions in cuboid diamonds from Udachnaya pipe from previous studies Zedgenizov et al. (2007) (2); and Klein-BenDavid et al. (2014) (3); [11,60] and with melt inclusions in olivine of sheared peridotite [61] (4). The arrow indicates suggested evolution of HDFs in process of percolation. Red field denotes the compositions of kimberlites from Udachnaya pipe [45]. The dotted lines correspond to the values of the primitive mantle [44].

Summarizing the above models, we conclude that it is possible to obtain the entire variety of HDFs in Udachnaya fibrous diamonds (in other localities, the evolution of melts may occur differently) by the evolution of a single parental melt that percolates through the lithospheric mantle by fractionation crystallization, interaction with surrounding rocks of different composition, or liquid immiscibility. The question is how to reveal this parental melt. The low nitrogen aggregation state in the Udachnaya fibrous diamonds, both cubic [11,13] and coated (this study), implies that their formation and HDF percolation took place shortly before the eruption of the Udachnaya kimberlite magma. This close temporal relation suggests a genetic link between HDFs and kimberlite magmatism. We propose that a small portion of the kimberlite melt (i.e., a precursory kimberlite melt or proto-kimberlite melt) could have segregated from the kimberlite source region and percolated upwards to form fibrous diamond before the kimberlite eruption event $[47,61,62]$.

It is now widely accepted that the primary kimberlite melt originated from the melting of carbonated peridotite and has a carbonatitic composition, i.e., $\mathrm{SiO}_{2}<20 \mathrm{wt} \%$ [45,61-69]. This statement has been recently evidenced at least for the Udachnaya kimberlite pipe. Olivine in unserpentinized xenoliths of Udachnaya sheared peridotites, derived from 180-230 km depths, contains melt inclusions that were interpreted to represent snapshots of the most primitive (i.e., close-to-primary) kimberlite melt. Bulk compositions of the melt inclusions in olivine of sheared peridotite are alkali-carbonatitic, indicating that the primary kimberlite melt was also alkali-carbonatitic [61,62]. These melt inclusions, as well as Udachnaya unaltered kimberlites, are plotted at the beginning of the HDF evolution trend in the $\mathrm{Th} / \mathrm{Nb}$ and $\mathrm{La} / \mathrm{Nb}$ diagram (Figure 8 ) and suggest that the primary kimberlite melt of carbonatitic composition could be parental to HDFs in fibrous diamonds. Sr isotope compositions of Udachnaya high-Mg carbonatitic HDFs are similar to those of the unaltered host kimberlites $[60,70]$ and the asthenosphere mantle. This similarity also suggests a genetic link between at least high-Mg carbonatitic HDFs in Udachnaya and the primary kimberlite melt. Note, that high-Mg carbonatitic HDFs with a Sr 
isotopic composition similar to that of the host kimberlites [60] also fall at the beginning of the HDF evolution trend in the $\mathrm{Th} / \mathrm{Nb}$ and $\mathrm{La} / \mathrm{Nb}$ diagram (Figure 8 ).

HDFs in Udachnaya fibrous diamonds are subdivided into high-Mg carbonatitic and low-Mg carbonatitic to silicic. Assuming that the high-Mg carbonatitic melt is the parent of all other HDFs (because high-Mg carbonatitic HDFs with a kimberlite-like Sr isotope composition lie in the beginning of evolution trend in Figure 8), it is possible to explain the formation of low-Mg carbonatitic to silicic HDFs by the interaction of the high-Mg carbonatitic melt with lithospheric rocks of different lithology. According to reactive melt transport models, the composition of the melt migrating through a mantle rock shifts towards that of a partial melt of this mantle rock [71,72]. That is, for example, if a carbonatitic melt with composition " $\mathrm{A}$ " percolates through peridotite with composition " $\mathrm{B}$ " and they are not in equilibrium at a given pressure and temperature, then this melt should evolve to an equilibrium composition of a partial melt in the system " $\mathrm{A}+\mathrm{B}$ ". For instance, high pressure experiments showed that a partial melt in the eclogite- $\mathrm{CO}_{2}$ system is carbonatitic at low temperature and silicic at relatively high temperature [73]. Therefore, if the initial high-Mg carbonatitic melt moves through the eclogite mantle, it should evolve to a low-Mg carbonatitic to silicic composition at high temperature. The silicic HDFs in coats of Udachnaya diamonds with cores of eclogitic paragenesis (inclusions of eclogitic minerals) support this idea. Golovin et al. $(2018,2019)$ demonstrated that primary Udachnaya kimberlite melt could be water-poor [61,62]. The high-Mg carbonatitic HDFs are also water-poor with a low water/carbonate ratio whereas the low-Mg carbonatitic to silicic HDFs are significantly enriched in water compared to carbonates. High-Mg carbonatitic HDFs may evolve to water-rich silicic ones via interaction with phlogopite peridotites. For instance, in the "peridotite-carbonate melt" system, the composition of partial melts depends on the bulk water content in the system [74]. When the bulk water content in the "peridotite-carbonate melt" system is low, the partial melt is carbonatitic whereas when bulk $\mathrm{H}_{2} \mathrm{O}>8 \mathrm{wt} \%$, the partial melts are hydrous silicic [74]. Therefore, if a small amount of carbonatitic melt infiltrates phlogopite peridotite, this should create a peridotite- $\mathrm{H}_{2} \mathrm{O}-\mathrm{CO}_{2}$ system with a high water/ $\mathrm{CO}_{2}$ ratio, and the reaction of a carbonatitic melt with phlogopite peridotite should produce a hydrous silicic melt or a more water-rich carbonatitic melt. Thus, mineral inclusions of peridotitic paragenesis in the studied coated diamonds with a high-Mg carbonatitic composition of microinclusions probably indicate a water-poor diamond-forming media during the growth of the coats. It is difficult to explain the formation of chloride-carbonate (saline) melt by the interaction of Mg-rich carbonatitic melt with mantle rocks because of the absence of $\mathrm{Cl}$-rich mantle rocks in the lithosphere. The primary kimberlite melt of Udachnaya is also enriched in $\mathrm{Cl}[61,62]$. The chloride-carbonate melt may originate as residual from the fractional crystallization of the initial carbonatitic HDFs or by the exsolution of the carbonatitic melt due to immiscibility. The compositional variations of HDFs in fibrous diamonds from other localities may depend on the primary composition of the transporting melt and mantle column as well.

\section{Conclusions}

The fibrous rims of coated diamonds from the Udachnaya kimberlite pipe represent the last generation of the mineral and are closely related in time to their host kimberlite eruption. The nitrogen aggregation in coated diamonds indicates multiple growth events that were significantly separated in time. The high nitrogen aggregation state in cores reflects their long residence time in the mantle whereas the presence of $C$ centers in the coats indicates that they were formed shortly before the kimberlite eruption. The carbon isotope composition reflects diverse carbon sources for the cores and coats of such crystals. The variations in the carbon isotope composition suggest that the coats formed from an isotopically homogeneous source, whereas the cores formed from a heterogeneous source.

Microinclusions in the coats of the studied diamonds represent daughter associations of high-Mg carbonatitic and low-Mg carbonatitic to silicic HDFs. The high-Mg carbonatitic HDFs have a genetic link with peridotitic host rocks, while the origin of low-Mg carbonatitic to silicic HDFs is related to eclogitic paragenesis. The trace element patterns of these HDFs support formation via percolation of 
the fluid/melt through various mantle rocks. It is suggested that some portion of the kimberlite melt could have segregated from the kimberlite source region at the pre-eruption stage and moved upward, resulting in the formation of fibrous coats. The high-Mg carbonatitic HDFs from most Udachnaya diamonds are close to the carbonatitic composition of the primary kimberlite melts in olivine [61] and have trace elements patterns similar to the host kimberlite $[11,70]$. This indicates that the evolution of HDFs could proceed from the parental high-Mg carbonatitic melt. The compositional variations of HDFs in Udachnaya fibrous diamonds may be explained by the evolution of a single parental carbonatitic melt during reactive percolation through the sub-craton lithospheric mantle.

Author Contributions: Conceptualization, D.Z. and I.S.; Methodology, N.G., D.Z., and A.R.; Formal analysis, investigation and data curation, N.G.; Writing-original draft preparation, N.G. and D.Z.; Writing-review and editing, I.S.

Funding: This study has been supported by Russian Science Foundation (16-17-10067).

Conflicts of Interest: The authors declare no conflict of interest.

\section{Appendix A}
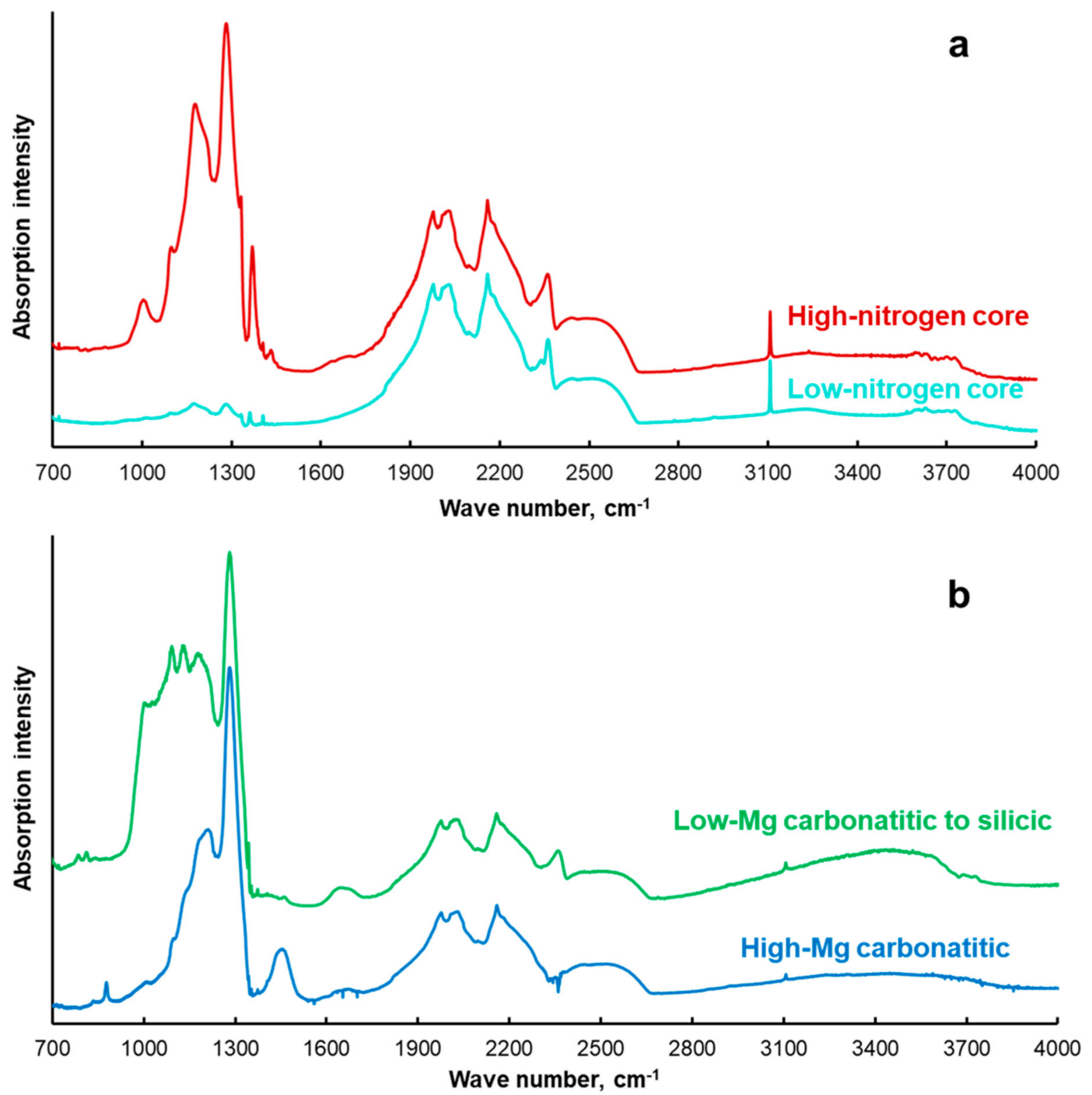

Figure A1. Example FTIR spectra of cores (a) and coats with low-Mg carbonatitic to silicic and high-Mg carbonatitic microinclusions (b). 
Table A1. Trace-element composition of microinclusions from coated diamonds, ppm. The values were normalized to the Fe content determined from EDS analysis.

\begin{tabular}{ccccccccc}
\hline Sample & Ud-4 & Ud-6 & Ud-12 & Ud-14 & Ud-17 & Ud-18 & Ud-21 & Ud-22 \\
\hline $\mathrm{Rb}$ & 500 & 277 & $<\mathrm{DL}$ & 609 & 993 & 486 & 1392 & $<\mathrm{DL}$ \\
$\mathrm{Ba}$ & 16,082 & 9443 & 20,623 & 10,856 & 16,422 & 10,745 & 20,561 & 11,607 \\
$\mathrm{Th}$ & 94.5 & 80.5 & 115 & 43.3 & 186 & 110 & 148 & 79.1 \\
$\mathrm{U}$ & 16.8 & 16.0 & 29.6 & 12.8 & 22.5 & 23.2 & 25.5 & 20.3 \\
$\mathrm{~K}$ & 195,414 & 117,276 & 209,423 & 114,082 & 193,507 & 151,191 & 301,637 & 130,591 \\
$\mathrm{Ta}$ & 30.6 & 4.96 & 0.745 & 22.0 & 62.4 & 3.78 & 8.03 & 14.4 \\
$\mathrm{Nb}$ & 604 & 109 & 83.4 & 133 & 1607 & 206 & 165 & 366 \\
$\mathrm{La}$ & 741 & 420 & 4487 & 425 & 1383 & 789 & 1144 & 505 \\
$\mathrm{Ce}$ & 980 & 436 & 1737 & 549 & 2275 & 1274 & 1588 & 487 \\
$\mathrm{Pr}$ & 91.2 & 34.0 & 163 & 77.1 & 158 & 110 & 108 & 38.7 \\
$\mathrm{Sr}$ & 3000 & 737 & 5000 & 6141 & 6074 & 3722 & 3399 & 1198 \\
$\mathrm{Nd}$ & 314 & 98.3 & 294 & 196 & 527 & 347 & 648 & 140 \\
$\mathrm{Sm}$ & 88.8 & 28.1 & 38.4 & 84.5 & $<\mathrm{DL}$ & 127 & 180 & 31.3 \\
$\mathrm{Hf}$ & 81.0 & 58.3 & 27.1 & 95.7 & $<\mathrm{DL}$ & 26.2 & 319 & 10.6 \\
$\mathrm{Zr}$ & 1851 & 1842 & 569 & 5920 & 472 & 790 & 4176 & 275 \\
$\mathrm{Eu}$ & 24.8 & 8.79 & 17.0 & 25.4 & 3.39 & 23.4 & 179 & 13.9 \\
$\mathrm{Ti}$ & 34,112 & 27,998 & 33,563 & 11,605 & $<\mathrm{DL}$ & 31,409 & 30,448 & 24,112 \\
$\mathrm{Gd}$ & 88.8 & 34.9 & 19.3 & 24.6 & 12.2 & 46.0 & 201 & 27.4 \\
$\mathrm{~Tb}$ & 12.6 & 4.24 & 2.22 & 7.93 & 1.55 & 7.04 & 23.3 & 3.45 \\
$\mathrm{Dy}$ & 77.0 & 18.3 & 12.8 & 14.4 & $<\mathrm{DL}$ & 29.2 & 92.3 & $<\mathrm{DL}$ \\
$\mathrm{Y}$ & 302 & 82.1 & 36.8 & 40.7 & 12.2 & 88.7 & 616 & 47.3 \\
$\mathrm{Ho}$ & 15.6 & 3.29 & 1.52 & 16.4 & 1.48 & 5.19 & 21.9 & 2.46 \\
$\mathrm{Er}$ & 38.8 & 8.78 & 15.8 & 23.8 & 18.8 & 10.9 & 48.4 & 7.10 \\
$\mathrm{Yb}$ & 20.4 & 4.15 & $<\mathrm{DL}$ & 22.2 & 6.94 & 14.7 & 11.6 & $<\mathrm{DL}$ \\
$\mathrm{Lu}$ & 2.29 & 0.832 & 0.419 & 9.81 & $<\mathrm{DL}$ & $<\mathrm{DL}$ & 5.33 & 1.40 \\
\hline & & & $<\mathrm{DL}-\mathrm{concentrations} \mathrm{below}$ detection limit. & &
\end{tabular}

\section{References}

1. Sobolev, N.V. Deep-Seated Inclusions in Kimberlites and the Upper-Mantle Composition; Nauka: Novosibirsk, Russia, 1974. (In Russian)

2. Meyer, H.O.A. Inclusions in Diamond. In Mantle Xenoliths; Nixon, P.H., Ed.; Wiley: Chichester, UK, 1987; pp. 501-522.

3. Harris, J.W. Diamond Geology. In The Properties of Natural and Synthetic Diamond; Field, J.E., Ed.; Academic Press: London, UK, 1992; pp. 345-349.

4. Chrenko, R.; McDonald, R.; Darrow, K. Infra-red spectra of diamond coat. Nature 1967, 213, 474-476. [CrossRef]

5. Guthrie, G.D.; Veblen, D.R.; Navon, O.; Rossman, G.R. Submicrometer fluid inclusions in turbid-diamond coats. Earth Planet. Sci. Lett. 1991, 105, 1-12. [CrossRef]

6. Navon, O.; Hutcheon, I.D.; Rossman, G.R.; Wasserburg, G.J. Mantle-derived fluids in diamond micro-inclusions. Nature 1988, 335, 784-789. [CrossRef]

7. Wyllie, P.J.; Ryabchikov, I.D. Volatile components, magmas, and critical fluids in upwelling mantle. J. Petrol. 2000, 41, 1195-1206. [CrossRef]

8. Schrauder, M.; Navon, O. Hydrous and carbonatitic mantle fluids in fibrous diamonds from Jwaneng, Botswana. Geoch. Cosmochim. Acta 1994, 58, 761-771. [CrossRef]

9. Izraeli, E.S.; Harris, J.W.; Navon, O. Brine inclusions in diamonds: A new upper mantle fluid. Earth Planet. Sci. Lett. 2001, 187, 323-332. [CrossRef]

10. Zedgenizov, D.A.; Kagi, H.K.; Shatsky, V.S.; Sobolev, N.V. Carbonatitic melts in cuboid diamonds from Udachnaya kimberlite pipe (Yakutia): Evidence from vibrational spectroscopy. Mineral. Mag. 2004, 68, 61-73. [CrossRef]

11. Zedgenizov, D.A.; Ragozin, A.L.; Shatsky, V.S. Compositional features of diamond growth medium: From the study of microinclusions in natural diamonds. Proc. Russ. Miner. Soc. 2007, 7, 159-172. 
12. Zedgenizov, D.A.; Ragozin, A.L.; Shatsky, V.S.; Araujo, D.; Griffin, W.L.; Kagi, H. Mg and Fe-rich carbonate-silicate high-density fluids in cuboid diamonds from the Internationalnaya kimberlite pipe (Yakutia). Lithos 2009, 112, 638-647. [CrossRef]

13. Zedgenizov, D.A.; Ragozin, A.L.; Shatsky, V.S.; Griffin, W.L. Diamond formation during metasomatism of mantle eclogite by chloride-carbonate melt. Contrib. Miner. Petrol. 2018, 173, 84. [CrossRef]

14. Shiryaev, A.A.; Izraeli, E.S.; Hauri, E.H.; Zakharchenko, O.D.; Navon, O. Chemical, optical and isotopic investigation of fibrous diamonds from Brazil. Russ. Geol. Geophys. 2005, 46, 1185-1201.

15. Tomlinson, E.L.; Jones, A.P.; Harris, J.W. Co-existing fluid and silicate inclusions in mantle diamond. Earth Planet. Sci. Lett. 2006, 250, 581-595. [CrossRef]

16. Logvinova, A.M.; Wirth, R.; Fedorova, E.; Sobolev, N. Nanometre-sized mineral and fluid inclusions in cloudy Siberian diamonds: New insights on diamond formation. Eur. J. Miner. 2008, 20, 317-331. [CrossRef]

17. Logvinova, A.M.; Wirth, R.; Tomilenko, A.A.; Afanas'ev, V.P.; Sobolev, N.V. The phase composition of crystal-fluid nanoinclusions in alluvial diamonds in the northeastern Siberian Platform. Russ. Geol. Geophys. 2011, 52, 1286-1297. [CrossRef]

18. Klein-BenDavid, O.; Izraeli, E.S.; Hauri, E.; Navon, O. Fluid inclusions in diamonds from the Diavik mine, Canada and the evolution of diamond-forming fluids. Geochim. Cosmochim. Acta 2007, 71, 723-744. [CrossRef]

19. Klein-BenDavid, O.; Logvinova, A.M.; Schrauder, M.; Spetius, Z.V.; Weiss, Y.; Hauri, E.H.; Kaminsky, F.V.; Sobolev, N.V.; Navon, O. High-Mg carbonatitic microinclusions in some Yakutian diamonds-A new type of diamond-forming fluid. Lithos 2009, 112, 648-659. [CrossRef]

20. Weiss, Y.; Kessel, R.; Griffin, W.L.; Kiflawi, I.; Klein-BenDavid, O.; Bell, D.R.; Harris, J.W.; Navon, O. A new model for the evolution of diamond-forming fluids: Evidence from microinclusion-bearing diamonds from Kankan, Guinea. Lithos 2009, 112, 660-674. [CrossRef]

21. Weiss, Y.; McNeill, J.; Pearson, D.G.; Nowell, G.M.; Ottley, C.J. Highly saline fluids from a subducting slab as the source for fluid-rich diamonds. Nature 2015, 524, 339. [CrossRef]

22. Skuzovatov, S.Y.; Zedgenizov, D.A.; Ragozin, A.L.; Shatsky, V.S. Growth medium composition of coated diamonds from the Sytykanskaya kimberlite pipe (Yakutia). Russ. Geol. Geophys. 2012, 53, 1197-1208. [CrossRef]

23. Boyd, S.R.; Mattey, D.P.; Pillinger, C.T.; Milledge, H.J.; Mendelssohn, M.; Seal, M. Multiple growth events during diamond genesis: An integrated study of carbon and nitrogen isotopes and nitrogen aggregation state in coated stones. Earth Planet. Sci. Lett. 1987, 86, 341-353. [CrossRef]

24. Boyd, S.R.; Kiflawi, I.; Woods, G.S. The relationship between infrared absorption and the A defect concentration in diamond. Philos. Mag. B 1994, 69, 1149-1153. [CrossRef]

25. Cartigny, P.; Harris, J.W.; Javoy, M. Diamond genesis, mantle fractionation and mantle nitrogen content: A study of $\delta 13 C-N$ concentrations in diamonds. Earth Planet. Sci. Lett. 2001, 185, 85-98. [CrossRef]

26. Yelisseyev, A.P.; Pokhilenko, N.P.; Steeds, J.W.; Zedgenizov, D.A.; Afanasiev, V.P. Features of coated diamonds from the Snap Lake/King Lake kimberlite dyke, Slave craton, Canada, as revealed by optical topography. Lithos 2004, 77, 83-97. [CrossRef]

27. Kinny, P.D.; Griffin, B.J.; Heaman, L.M.; Brakhfogel, F.F.; Spetsius, Z.V. SHRIMP U-Pb ages of perovskite from Yakutian kimberlites. Russ. Geol. Geophys. 1997, 38, 97-105.

28. Woods, G.S.; Purser, G.C.; Mtimkulu, A.S.S.; Collins, A.T. The nitrogen content of type Ia natural diamonds. J. Phys. Chem. Solids. 1990, 51, 1191-1197. [CrossRef]

29. Harte, B.; Fitzsimons, I.C.W.; Harris, J.W.; Otter, M.L. Carbon isotope ratios and nitrogen abundances in relation to cathodoluminescence characteristics for some diamonds from the Kaapvaal Province, S-Africa. Mineral. Mag. 1999, 63, 829. [CrossRef]

30. Rege, S.; Jackson, S.; Griffin, W.L.; Davies, R.M.; Pearson, N.J.; O’Reilly, S.Y. Quantitative trace-element analysis of diamond by laser ablation inductively coupled plasma mass spectrometry. J. Anal. At. Spectrom. 2005, 20, 601-611. [CrossRef]

31. Orlov, Y.L. Mineralogy of Diamond, 2nd ed.; Nauka: Moscow, Russia, 1984; p. 264. (In Russian)

32. Khokhryakov, A.F.; Palyanov, Y.N. The evolution of diamond morphology in the process of dissolution: Experimental data. Am. Mineral. 2007, 92, 909-917. [CrossRef]

33. Sunagawa, I. Growth and morphology of diamond crystals under stable and metastable conditions. J. Cryst. Growth 1990, 99, 1156-1161. [CrossRef] 
34. Kaiser, W.; Bond, W. Nitrogen, a major impurity in common type I diamond. Phys. Rev. 1959, $115,857$. [CrossRef]

35. Sobolev, E.V.; Lisoivan, V.I. Nitrogen Centers and Growth of Natural Diamond. In Problems of Crustal and Upper-Mantle Petrology; Sobolev, V.S., Ed.; Nauka: Novosibirsk, Russia, 1978; pp. 245-255. (In Russian)

36. Jones, R.; Briddon, P.R.; Öberg, S. First-principles theory of nitrogen aggregates in diamond. Philos. Mag. Lett. 1992, 66, 67-74. [CrossRef]

37. Smith, W.; Sorokin, P.; Gelles, I.; Lasher, G. Electron-spin resonance of nitrogen donors in diamond. Phys. Rev. 1959, 115, 1546. [CrossRef]

38. Goss, J.P.; Coomer, B.J.; Jones, R.; Fall, C.J.; Briddon, P.R.; Öberg, S. Extended defects in diamond: The interstitial platelet. Phys. Rev. 2003, 67, 165208. [CrossRef]

39. Woods, G.S. Platelets and the infrared absorption of type Ia diamonds. Proc. R. Soc. Lond. Ser. A 1986, 407, 219-238. [CrossRef]

40. Woods, G.S.; Collins, A.T. Infrared absorption spectra of hydrogen complex in type I diamonds. J. Phys. Chem. Solids 1983, 44, 471-475. [CrossRef]

41. Stachel, T.; Harris, J.W. The origin of cratonic diamonds-Constraints from mineral inclusions. Ore Geol. Rev. 2008, 34, 5-32. [CrossRef]

42. Sobolev, N.V.; Logvinova, A.M.; Zedgenizov, D.A.; Pokhilenko, N.P.; Malygina, E.V.; Kuzmin, D.V.; Sobolev, A.V. Petrogenetic significance of minor elements in olivines from diamonds and peridotite xenoliths from kimberlites of Yakutia. Lithos 2009, 112, 701-713. [CrossRef]

43. Stachel, T.; Harris, J.W.; Muehlenbachs, K. Sources of carbon in inclusion bearing diamonds. Lithos 2009, 112, 625-637. [CrossRef]

44. McDonough, W.F.; Sun, S.S. The composition of the Earth. Chem. Geol. 1995, 120, 223-253. [CrossRef]

45. Kamenetsky, V.S.; Kamenetsky, M.B.; Golovin, A.V.; Sharygin, V.V.; Maas, R. Ultrafresh salty kimberlite of the Udachnaya-East pipe (Yakutia, Russia): A petrological oddity or fortuitous discovery? Lithos 2012, 152, 173-186. [CrossRef]

46. Evans, T.; Qi, Z. The kinetics of the aggregation of nitrogen atoms in diamond. Proc. R. Soc. Lond. Ser. A 1982, 381, 159-178. [CrossRef]

47. Sharygin, I.S.; Litasov, K.D.; Shatskiy, A.; Golovin, A.V.; Ohtani, E.; Pokhilenko, N.P. Melting phase relations of the Udachnaya-East Group-I kimberlite at 3.0-6.5 GPa: Experimental evidence for alkali-carbonatite composition of primary kimberlite melts and implications for mantle plumes. Gondwana Res. 2015, 28, 1391-1414. [CrossRef]

48. Ragozin, A.L.; Palyanov, Y.N.; Zedgenizov, D.A.; Kalinin, A.A.; Shatsky, V.S. The Homogenization of Carbonate-Containing Microinclusions in Diamonds at Upper Mantle P-T Parameters. In Proceedings of the 26th Goldschmidt Conference, Yokohama, Japan, 1-26 July 2016.

49. Taylor, W.R.; Canil, D.; Millendge, H.J. Kinetics of Ib to IaA nitrogen aggregation in diamond. Geochim. Cosmochim. Acta 1996, 60, 4725-4733. [CrossRef]

50. Galimov, E.M. Isotope fractionation related to kimberlite magmatism and diamond formation. Geoch. Cosmochim. Acta 1991, 55, 1697-1708. [CrossRef]

51. Deines, P. The carbon isotope composition of diamonds: Relationship to diamond shape, color, occurrence and vapor composition. Geoch. Cosmochim. Acta 1980, 44, 943-961. [CrossRef]

52. Reutsky, V.N.; Palyanov, Y.N.; Borzdov, Y.M.; Sokol, A.G. Isotope fractionation of carbon during diamond crystallization in model systems. Russ. Geol. Geophys. 2015, 56, 239-244. [CrossRef]

53. Javoy, M.; Pineau, F.; Delorme, H. Carbon and nitrogen isotopes in the mantle. Chem. Geol. 1986, 57, 41-62. [CrossRef]

54. McCandless, T.E.; Gurney, J.J. Diamond eclogites: Comparison with carbonaceous chondrites, carbonaceous shales, and microbial carbon-enriched MORB. Russ. Geol. Geophys. 1997, 38, 394-404.

55. Sobolev, N.V.; Galimov, E.M.; Ivanovskaia, I.N.; Yefimova, E.S. Isotopic composition of carbon from diamonds containing crystalline inclusions. Dokl. Akad. Nauk SSSR 1979, 249, 1217-1220. (In Russian)

56. Perchuk, L.L.; Safonov, O.G.; Yapaskurt, V.O.; Barton, J.M., Jr. Crystal-melt equilibria involving potassium-bearing clinopyroxene as indicator of mantle-derived ultrahigh-potassic liquids: An analytical review. Lithos 2002, 60, 89-111. [CrossRef]

57. Navon, O.; Izraeli, E.S.; Klein-BenDavid, O. Fluid Inclusions in Diamonds-the Carbonatitic Connection. In Proceedings of the 8th international Kimberlite Conference, Victoria, BC, Canada, 22-27 June 2003. 
58. Safonov, O.G.; Perchuk, L.L.; Litvin, Y.A. Melting relations in the chloride-carbonate-silicate systems at high-pressure and the model for formation of alkalic diamond-forming liquids in the upper mantle. Earth Planet. Sci. Lett. 2007, 253, 112-128. [CrossRef]

59. Weiss, Y.; Griffin, W.L.; Navon, O. Diamond-forming fluids in fibrous diamonds: The trace-element perspective. Earth. Planet. Sci. Lett. 2013, 376, 110-125. [CrossRef]

60. Klein-BenDavid, O.; Pearson, D.G.; Nowell, G.M.; Ottley, C.; McNeill, J.C.R.; Logvinova, A.M.; Sobolev, N.V. The sources and time-integrated evolution of diamond-forming fluids-Trace elements and isotopic evidence. Geochim. Cosmochim. Acta 2014, 125, 146-169. [CrossRef]

61. Golovin, A.V.; Sharygin, I.S.; Kamenetsky, V.S.; Korsakov, A.V.; Yaxley, G.M. Alkali-carbonate melts from the base of cratonic lithospheric mantle: Links to kimberlites. Chem. Geol. 2018, 483, 261-274. [CrossRef]

62. Golovin, A.V.; Sharygin, I.S.; Korsakov, A.V.; Kamenetsky, V.S.; Abersteiner, A. Can primitive kimberlite melts be alkali-carbonate liquids: Composition of the melt snapshots preserved in deepest mantle xenoliths. J. Raman Spectrosc. 2019. [CrossRef]

63. Russell, J.K.; Porritt, L.A.; Lavallee, Y.; Dingwell, D.B. Kimberlite ascent by assimilation-fuelled buoyancy. Nature 2012, 481, 352-356. [CrossRef]

64. Giuliani, A.; Kamenetsky, V.S.; Phillips, D.; Kendrick, M.A.; Wyatt, B.A.; Goemann, K. Nature of alkali-carbonate fluids in the subcontinental lithospheric mantle. Geology 2012, 40, 967-970. [CrossRef]

65. Sharygin, I.S.; Golovin, A.V.; Korsakov, A.V.; Pokhilenko, N.P. Tychite in mantle xenoliths from kimberlites: The first find and a new genetic type. Dokl. Earth Sci. 2016, 467, 270-274. [CrossRef]

66. Stone, R.S.; Luth, R.W. Orthopyroxene survival in deep carbonatite melts: Implications for kimberlites. Contrib. Mineral. Petrol. 2016, 171, 63. [CrossRef]

67. Shatskiy, A.; Litasov, K.D.; Sharygin, I.S.; Ohtani, E. Composition of primary kimberlite melt in a garnet lherzolite mantle source: Constraints from melting phase relations in anhydrous Udachnaya-East kimberlite with variable $\mathrm{CO}_{2}$ content at $6.5 \mathrm{GPa}$. Gondwana Res. 2017, 45, 208-227. [CrossRef]

68. Golovin, A.V.; Sharygin, I.S.; Korsakov, A.V. Origin of alkaline carbonates in kimberlites of the Siberian craton: Evidence from melt inclusions in mantle olivine of the Udachnaya-East pipe. Chem. Geol. 2017, 455, 357-375. [CrossRef]

69. Kamenetsky, V.S.; Kamenetsky, M.B.; Sobolev, A.V.; Golovin, A.V.; Demouchy, S.; Faure, K.; Sharygin, V.V.; Kuzmin, D.V. Olivine in the Udachnaya-East kimberlite (Yakutia, Russia): Types, compositions and origins. J. Petrol. 2007, 49, 823-839. [CrossRef]

70. Kamenetsky, V.S.; Maas, R.; Kamenetsky, M.B.; Paton, C.; Phillips, D.; Golovin, A.V.; Gornova, M.A. Chlorine from the mantle: Magmatic halides in the Udachnaya-East kimberlite, Siberia. Earth Planet. Sci. Lett. 2009, 285, 96-104. [CrossRef]

71. Reiners, P.W. Reactive melt transport in the mantle and geochemical signatures of mantle-derived magmas. J. Petrol. 1998, 39, 1039-1061. [CrossRef]

72. Sharygin, I.S.; Shatskiy, A.; Litasov, K.D.; Golovin, A.V.; Ohtani, E.; Pokhilenko, N.P. Interaction of peridotite with Ca-rich carbonatite melt at 3.1 and 6.5 GPa: Implication for merwinite formation in upper mantle, and for the metasomatic origin of sublithospheric diamonds with Ca-rich suite of inclusions. Contrib. Mineral. Petrol. 2018, 173, 22. [CrossRef]

73. Litasov, K.D.; Safonov, O.G.; Ohtani, E. Origin of Cl-bearing silica-rich melt inclusions in diamond: Experimental evidences for eclogite connection. Geology 2010, 38, 1131-1134. [CrossRef]

74. Sokol, A.G.; Kupriyanov, I.N.; Palyanov, Y.N. Partitioning of $\mathrm{H}_{2} \mathrm{O}$ between olivine and carbonate-silicate melts at $6.3 \mathrm{GPa}$ and $1400^{\circ} \mathrm{C}$ : Implications for kimberlite formation. Earth. Planet. Sci. Lett. 2013, 383, 58-67. [CrossRef]

(C) 2019 by the authors. Licensee MDPI, Basel, Switzerland. This article is an open access article distributed under the terms and conditions of the Creative Commons Attribution (CC BY) license (http://creativecommons.org/licenses/by/4.0/). 